\title{
DIAGNOSIS INFEKSI SITOMEGALOVIRUS PADA BAYI DAN ANAK
}

\author{
Novi H. Rampengan
}

\author{
Bagian Ilmu Kesehatan Anak Fakultas Kedokteran Universitas Sam Ratulangi Manado \\ Email: novierampengan@yahoo.com
}

\begin{abstract}
The prevalence of cytomegaloviral (CMV) infection is still high in developing countries, including Indonesia. CMV often causes intra-uterine infection with an incidence of 7 per 1,000 live births. Around $12.7 \%$ of babies with CMV infection develop symptoms since birth and around $13.5 \%$ of babies without any symptom develop sequel, including disruption of sensorineural hearing when the children age. CMV can be diagnosed with a single or combined examination by using amniocentesis, virus culture, PCR, antigenemia plus serologic IgM and IgG CMV, however, it is important to understand when these examinations will be performed and to evaluate the interpretation.
\end{abstract}

Keywords: CMV, diagnosis, single examination, combined examination

\begin{abstract}
Abstrak: Prevalensi infeksi sitomegalovirus (CMV) masih tinggi di negara berkembang, termasuk Indonesia. CMV sering dapat menyebabkan infeksi intra-uterin dengan insidensi 7 per 1000 kelahiran hidup. Sebanyak 12,7\% bayi yang terinfeksi CMV memperlihatkan gejala saat lahir dan sebanyak 13,5\% bayi yang tidak memperlihatkan gejala berkembang menjadi sekuele termasuk di dalamnya gangguan pendengaran sensorineural saat anak-anak. Diagnosis CMV dapat dilakukan dengan pemeriksaan tunggal maupun kombinasi menggunakan amniosintesis, kultur virus, PCR, antigenemia serta serologi IgM dan IgG CMV, namun penting untuk mengetahui saat dilakukan pemeriksaan tersebut dan bagaimana interpretasinya.

Kata kunci: CMV, diagnosis, pemeriksaan tunggal, pemeriksaan kombinasi
\end{abstract}

Infeksi kongenital sitomegalovirus (cytomegalovirus/CMV) merupakan salah satu infeksi virus paling umum yang menyebabkan infeksi kongenital. ${ }^{1}$ Infeksi CMV pada manusia tersebar di seluruh dunia dan merupakan infeksi virus patogen terpenting sejak dahulu. ${ }^{2}$ Infeksi CMV bersifat endemis dan tidak bergantung pada musim tertentu. Di Amerika Serikat, seroprevalensi CMV mencapai 50\% sehingga wanita hamil dengan usia produktif memiliki risiko terjadinya infeksi primer CMV. Angka seroprevalensi tersebut mencapai $40-80 \%$ di negara maju dan $90-100 \%$ di negara berkembang., ${ }^{2,3}$ CMV sering menyebabkan infeksi intra- uterin dengan insidensi mencapai 0,032,0\% dari semua bayi lahir hidup atau 7 per 1000 kelahiran hidup. ${ }^{4,5}$ Sebanyak 12,7\% bayi yang terinfeksi memperlihatkan gejala saat lahir dan sebanyak 13,5\% bayi yang tidak memperlihatkan gejala berkembang menjadi sekuele termasuk di dalamnya gangguan pendengaran sensorineural saat anak-anak. ${ }^{5}$ Infeksi CMV pada umumnya didapat dalam tahun pertama kehidupan pada negara dengan pendapatan ekonomi rendah, sedangkan di negara maju, infeksi ini muncul pada akhir masa anak-anak. ${ }^{1,4}$

CMV ditransmisikan melalui kontak dengan individu yang membawa infeksi CMV. Penyebab utama transmisi virus ke 
ibu hamil atau wanita muda usia produktif ialah dari anak kecil usia pra sekolah yang bermain atau dekat dengan wanita tersebut, namun dapat juga berasal dari pasangan atau kontak seksual. ${ }^{5,6}$ Transmisi dapat berasal dari semua cairan tubuh seperti urin, cairan semen, ludah, air mata, cairan serebrospinal, air susu ibu (ASI), transfusi darah, atau dari transplantasi organ. ${ }^{7}$

Transmisi CMV juga dapat terjadi secara fetomaternal selama hamil, saat persalinan, dan paparan pasca natal. Infeksi kongenital CMV dapat menunjukkan gejala atau tidak pada bayi baru lahir. Gejala terinfeksi CMV pada bayi yaitu kuning (62\%), hepatosplenomegali (50\%), dan petekie (58\%) yang merupakan trias klasik pada bayi dengan infeksi kongenital CMV; gejala tersebut sering ditemukan pada bayi baru lahir dengan pertumbuhan terhambat dan seringkali prematur. ${ }^{1,8}$ Transmisi intrauterin merupakan jalur utama transmisi yang dapat memberikan sekuele neurologis. Di negara industri yang memiliki banyak komunitas berpenghasilan rendah atau di negara berkembang, infeksi CMV didapatkan pada awal kehidupan disebabkan transmisi dari ASI dan kepadatan di tempat tinggal. Insidensi infeksi CMV pada bayi sampai usia 6 bulan di AS berkisar antara $35-56 \%$ yang diduga disebabkan karena pemberian ASI. ${ }^{8-10}$

Berdasarkan data bahwa 55\% bayi yang terinfeksi CMV tidak memperlihatkan gejala namun bisa berkembang menjadi sekuele, maka diagnosis yang tepat dan cepat sangat diperlukan. Terdapat banyak metode yang digunakan untuk mendiagnosis CMV. Amniosintesis dilakukan untuk skrining prenatal. Pemeriksaan baku emas untuk infeksi CMV kongenital ialah dengan kultur virus dari urin dan ludah yang diambil dalam 2 minggu kehidupan. ${ }^{1}$ Pemeriksaan lain yang dapat dilakukan seperti pemeriksaan serologik, polymerase chain reaction (PCR), dan antigenemia. Pemeriksaan serologik yang mendeteksi CMV menggunakan enzyme-linked immunosorbent assay (ELISA) indirek untuk melihat antibodi IgG dan IgM CMV. ${ }^{11}$ Pemeriksaan antibodi merupakan pemeriksaan yang umum dikerjakan. ${ }^{12}$

\section{DIAGNOSIS}

Dalam menegakkan diagnosis infeksi CMV pada bayi dan anak diperlukan pemeriksaan diagnostik yang ideal untuk mendeteksi infeksi aktif CMV serta membedakannya dari penyakit $\mathrm{CMV}^{13}$ Terdapat banyak metode yang digunakan baik sebagai pemeriksaan tunggal atau kombinasi untuk mendiagnosis $\mathrm{CMV}^{1}$ Pemeriksaan yang dilakukan harus mudah dan memberikan hasil yang cepat dan terpercaya. Hal ini berkaitan dengan perlunya mengetahui infeksi primer sejak dini agar dapat memantau perkembangan penyakit CMV. Infeksi kongenital CMV secara prenatal didiagnosis dengan mendeteksi IgM pada darah janin atau mengisolasi virus dari cairan amnion. Diagnosis CMV pada bayi baru lahir dapat dilakukan bergantung pada ada tidaknya virus dari pemeriksaan isolasi virus melalui urin, identifikasi DNA CMV dengan pemeriksaan PCR melalui urin, darah (termasuk darah kering), ludah dan cairan serebrospinal yang diambil dalam usia 3 minggu pertama pasca lahir, serta deteksi antigen atau IgM CMV dalam darah (Tabel 1).

\section{Amniosentesis}

Pemeriksaan amniosentesis sangat akurat setelah usia kehamilan 21 minggu, ketika ginjal janin sudah cukup matang untuk mengeksresikan virus ke cairan amnion. ${ }^{2,14}$ Meski demikian perlu dipertimbangkan besarnya risiko terjadinya aborsi spontan bila dilakukan suatu amniosentesis. $^{14}$

\section{Kultur virus}

Pemeriksaan baku emas untuk infeksi CMV kongenital ialah dengan kultur virus dari urin dan ludah yang diambil dalam 2 minggu kehidupan. ${ }^{1,12,15}$ Pemeriksaan CMV melalui ludah dan urin pada bayi baru lahir sangat diterima karena bayi dengan infeksi kongenital CMV mengandung banyak virus dalam sampelnya. Teknik kultur jaringan tradisional dan 
beberapa modifikasi, seperti metode kultur cepat dari sentrifugasi menggunakan antibodi monoklonal untuk pewarnaan berkemampuan mendapatkan protein pp72 dari CMV lebih cepat, sedang dipertimbangkan menjadi pemeriksaan umum untuk diagnosis. Metode kultur cepat ini menunjukkan sensitifitas dan spesifisitas yang dapat dibandingkan dengan kultur sel biasa. Hasil kultur cepat ini dapat diperoleh dalam 24-36 jam, dibandingkan kultur urin konvensional yang memerlukan 7-10 hari. Sensitivitas dan spesifisitas dari pemeriksaan ini ialah 94,5\% dan 100\% untuk mendeteksi CMV dari urin bayi dengan infeksi kongenital CMV.,12

Tabel 1. Ringkasan pemeriksaan CMV untuk diagnosis ${ }^{12}$

\begin{tabular}{lll}
\hline Metode & Spesimen & Keterangan \\
\hline Serologi & Darah & $\begin{array}{l}\text { IgG hanya bermanfaat untuk } \\
\text { menentukan infeksi lama; IgM } \\
\end{array}$ \\
& & $\begin{array}{l}\text { memiliki sensitifitas dan } \\
\text { spesitifitas rendah untuk } \\
\text { mengertahui infeksi baru }\end{array}$ \\
& & Memerlukan banyak waktu \\
Kultur sel & Darah, urin, ludah & Cepat, hasil semi-kuantitatif \\
Antigenemia & Darah & Sangat sensitif, mendeteksi \\
PCR & Darah, urin, ludah, jaringan & DNA/RNA virus, menentukan \\
& & banyaknya virus \\
\hline
\end{tabular}

\section{Polymerase chain reaction (PCR)}

Diagnosis infeksi CMV secara tepat dapat dilakukan dengan pemeriksaan DNA CMV. PCR merupakan pemeriksaan yang sangat sensitif untuk mendeteksi CMV dari berbagai sumber, seperti darah, urin, ludah dan jaringan. Pemeriksaan berkala DNA CMV dari darah tepi dengan pemeriksaan kuantitatif PCR dapat bermanfaat untuk mengidentifikasi penderita yang berisiko tinggi dan memantau efek terapi antiviral. ${ }^{8,12}$

Studi awal oleh Demmler et al. menunjukkan PCR memiliki sensitifitas dan spesitifitas sebesar 93\% dan 100\% untuk mendeteksi antigen $\mathrm{CMV} .{ }^{12}$ Studi lain oleh Warren et al. menunjukkan PCR memiliki sensitifitas dan spesifisitas sebesar 89,2\% dan 95,8\% dibandingkan dengan kultur jaringan dan kultur cepat dari saliva pada bayi dengan infeksi kongenital CMV. ${ }^{15}$ Kelemahan PCR yang paling memungkinkan ialah viremia tidak selalu muncul pada semua bayi dengan infeksi kongenital CMV di darah tepi ${ }^{16}$ serta dapat ditemukan kesulitan dalam pengambilan sampel urin dari bayi baru lahir. Kadambari et al. melaporkan kesulitan dalam mengambil sampel urin pada sepertiga dari seluruh sampel yang ditelitinya, dan menyimpulkan bahwa pengambilan sampel ludah lebih mudah diambil dan memiliki hasil yang sama dengan sampel urin. ${ }^{5}$

Sejak sampel darah kering atau dried blood spots (DBS) diambil pada seluruh bayi baru lahir di AS untuk skrining metabolik rutin, terjadi ketertarikan untuk menggunakan PCR pada darah kering untuk mendeteksi CMV pada bayi baru lahir. ${ }^{17,18}$ Pemeriksaan ini dapat dikerjakan secara retrospektif dimana pemeriksaan telah melewati 3 minggu pasca lahir sehingga bila terdapat gejala klinis yang menunjukkan infeksi CMV seperti gangguan pendengaran sensorineural pada anak yang lebih besar dapat diperiksa sampel darah kering untuk CMV. ${ }^{5}$ Keuntungan penggunaan sampel darah kering untuk skrining CMV pada bayi baru lahir ialah spesimen juga dapat digunakan untuk skrining metabolik rutin, dan PCR tidak memerlukan fasilitas kultur jaringan, 
dan biaya lebih murah. ${ }^{12}$

Pemeriksaan DNA CMV PCR pada sampel darah kering memiliki sensitifitas sekitar 34\% sampai $100 \%$ untuk infeksi kongenital CMV. ${ }^{5}$ Penelitian oleh Boppana et al. pada 20.000 bayi baru lahir yang membandingkannya dengan kultur cepat ludah menunjukkan pemeriksaan PCR sampel darah kering hanya mendeteksi $<40 \%$ bayi dengan infeksi kongenital CMV serta sensitifitas dan spesifitas yang ditunjukkan ialah 30,4\% dan 99,9\%. Hasil tersebut menunjukkan pemeriksaan ini tidak sesuai jika digunakan pada skrining masal untuk pemeriksaan infeksi kongenital CMV. Spesifisitas tinggi dari pemeriksaan ini berarti hasil yang positif menunjukkan infeksi kongenital CMV. Walau demikian hasil negatif tidak dapat mengeksklusi infeksi kongenital CMV pada bayi baru lahir. ${ }^{18}$

\section{Antigenemia}

Antigenemia juga merupakan salah satu pemeriksaan yang sering digunakan lebih dari satu dekade untuk mengetahui virus CMV secara kuantitatif dalam darah. Uji tersebut berdasarkan antibodi monoklonal yang mendeteksi antigen pp65 yaitu protein akhir yang diekspresikan leukosit pada fase replikasi CMV awal. Antigen ini diukur berdasarkan jumlah inti leukosit yang positif dengan uji imunofluoresens untuk matriks fosfoprotein pp65 CMV dari $2 \times 10^{5}$ leukosit darah tepi dalam preparat sitospin. Pemeriksaan ini terbatas untuk mendeteksi virus dari leukosit, yaitu adanya inti leukosit dengan pengecatan positif menunjukkan hasil positif. Uji ini tidak hanya memberikan hasil secara kualitatif tapi juga secara kuantitatif, dimana berhubungan dengan viremia dan beratnya gejala klinis penderita. Kelemahan uji antigenemia ialah bergantung pada tenaga ahli untuk melakukan pemeriksaan dan menginterpretasikan hasil. Selain itu, sampel harus diproses dengan cepat (dalam waktu 6 jam); makin lama pemeriksaan yang dilakukan akan mengurangi sensitifitas uji. Pada pasien dengan neutropenia dapat menunjukkan hasil negatif palsu karena tergantung pada jumlah leukosit polimorfonuklear yang cukup. Sensitifitas dan spesitifitas uji antigenemia CMV sebesar 64\% dan $81 \%$ berdasarkan studi yang dilakukan oleh Greanya et al. ${ }^{12,13,16,19}$

\section{Enzyme-linked immunosorbent assay (ELISA)}

Pemeriksaan diagnostik lain untuk infeksi CMV ialah pemeriksaan serologik yang mendeteksi CMV menggunakan ELISA indirek untuk melihat antibodi IgG dan IgM CMV. ${ }^{11}$ Pemeriksaan antibodi merupakan pemeriksaan yang umum dikerjakan. Deteksi antibodi IgM digunakan sebagai penanda infeksi akut atau rekurens. Antibodi IgM ibu tidak dapat ditransfer melalui plasenta. Hal ini berbeda dengan antibodi IgG pada bayi dan anak umumnya berasal dari transfer antibodi ibu. Terdeteksinya antibodi IgM dalam usia 2-3 minggu pascanatal menandakan adanya infeksi kongenital CMV. Meskipun demikian, hanya $70 \%$ bayi dengan infeksi kongenital CMV yang memiliki antibodi IgM saat lahir. Hal ini menyebabkan angka spesifisitas yang rendah pada infeksi primer dan hasilnya dapat positif palsu karena IgM dapat bertahan selama beberapa bulan setelah infeksi dan dapat positif oleh karena reaktivasi infeksi CMV. Bila pada pemeriksaan CMV didapatkan IgM positif, maka diagnosis harus dikonfirmasi dengan melihat ada tidaknya virus melalui kultur virus atau pemeriksaan PCR. ${ }^{1,2,11,13}$ Bila bayi mengalami infeksi CMV kongenital, antibodi IgG CMV akan memberikan hasil positif dengan titer yang semakin meninggi sampai bayi berusia 4-9 bulan; hal ini dapat membantu konfirmasi infeksi aktif CMV. Terdapatnya IgG CMV yang negatif pada darah tali pusat bayi menunjukan tidak adanya infeksi CMV kongenital, tetapi jika positif ada dua kemungkinan yaitu transfer pasif dari ibu atau adanya indikasi infeksi kongenital. $^{8,13}$

Untuk konfirmasi diagnosis infeksi CMV pada bayi dan anak diperlukan antibodi IgM CMV dan peningkatan titer antibodi IgG sebanyak empat kali. 
Pemeriksaan peningkatan titer ini dilakukan secara serial tiap 2-3 minggu. Tes antibodi IgG dipakai untuk mendeteksi infeksi yang telah terjadi sebelumnya atau di masa lalu. Bila hanya ada satu pemeriksaan IgG yang menunjukkan positif atau titer IgG mencapai fase tinggi mendatar (plateau) disertai dengan IgM yang positif, maka tidak mungkin membedakan infeksi primer dengan reaktivasi-reinfeksi atau dengan kemungkinan suatu stimulasi poliklonal. ${ }^{6,11}$

Infeksi baru dapat dibedakan dari infeksi lama dengan menetapkan $I g G$ avidity. Biasanya IgG yang diproduksi dalam 3-5 bulan setelah infeksi primer memiliki aviditas rendah, sedangkan IgG yang diproduksi lebih dari 3-5 bulan atau bertahun-tahun setelah infeksi primer memiliki aviditas tinggi. Selain untuk mengetahui apakah infeksi sudah lama atau baru terjadi, primer atau sekunder, pemeriksaan IgG avidity dapat pula dipakai untuk mempertimbangkan kemungkinan perlu pemberian terapi atau tidak. Studi yang dilakukan Harry et al. menunjukkan akurasi $>90 \%$ yang menghubungkan antara IgG aviditas yang rendah dengan kadar IgM CMV untuk mengetahui infeksi primer CMV. Penetapan IgG avidity dilakukan bersamaan waktu dengan penetapan IgG, karena interpretasi hasil IgG avidity tidak dapat dilakukan dengan baik bila kadar IgG $<6 \mathrm{aU} / \mathrm{ml}$ atau $>400 \mathrm{aU} / \mathrm{ml}$. Pemeriksaan harus diulang dan dilakukan pengenceran bila kadar IgG $>400 \mathrm{aU} / \mathrm{ml}^{6,11-13,20}$ (Gambar 1).

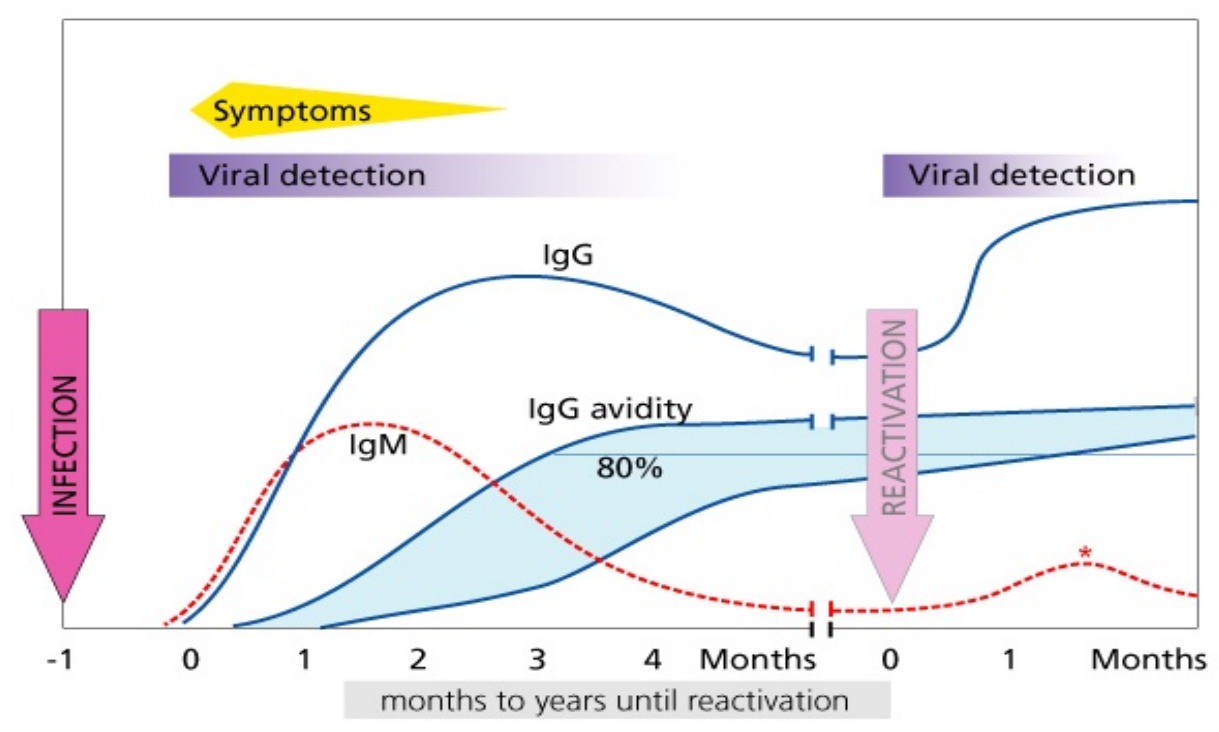

Gambar 1. Kurva titer antibodi infeksi CMV ${ }^{6,11-13,20}$

\section{Pemeriksaan kombinasi}

Ibu hamil dengan seronegatif 6 bulan sebelum konsepsi berpeluang untuk terinfeksi primer saat hamil. Pemeriksaan IgG perlu dilakukan sekurang-kurangnya dua kali yaitu pada 2 bulan dan 4 bulan kehamilan. Bila hasil negatif, maka tindakan lanjut dapat ditunda, tetapi bila didapatkan serokonversi, maka diagnosis infeksi primer ibu dan prenatal bayi dapat ditegakkan. Reinfeksi sering terjadi ketika hamil dan penetapan jumlah virus dapat dipakai untuk mengetahui risiko transmisi vertikal, sedangkan pada masa kehamilan, isolasi virus dari cairan amnion dipakai untuk mendeteksi infeksi in utero dikombinasikan dengan pemeriksaan darah fetus setelah 20 minggu kehamilan memberi hasil sensitivitas diagnostik 80-100\%.

Untuk deteksi kongenital, isolasi CMV dari darah tali pusat, urin, saliva, darah atau serum pada minggu pertama setelah lahir 
atau sebelum berumur 3 minggu, merupakan pemeriksaan penunjang untuk infeksi kongenital. Ekskresi CMV tersebut dapat dideteksi dengan metoda PCR, dan penemuan dalam darah menunjukkan prognosis yang jelek. Hasil IgM positif pada darah tali pusat yang diambil in utero atau saat lahir juga mempunyai arti diagnostik untuk infeksi kongenital. $1,4,12,14,21$

Pemeriksaan radiologis dilakukan pada janin dengan infeksi kongenital CMV untuk mengetahui apakah janin akan menderita infeksi dan gangguan perkembangan psikomotor. Pemeriksaan ultrasonografi dan MRI dapat dipercaya untuk memrediksi keluaran yang tidak baik pada anatomi janin. Temuan yang sering didapatkan pada janin dengan infeksi CMV ialah ventrikulomegali otak, mikrosefali, usus yang ekogenik, hepatosplenomegali, kalsifikasi intrakranial dan intraabdominal, restriksi pertumbuhan, serta pembesaran plasenta.

Pemeriksaan ultrasonografi (USG) dapat juga digunakan sebagai tambahan amniosentesis. Meski demikian, bila tidak didapatkan temuan, infeksi kongenital CMV tidak dapat disingkirkan karena hingga $47 \%$ janin dengan infeksi kongenital CMV memiliki gambaran USG normal. Bila diagnosis infeksi CMV pada janin belum dapat ditegakkan, maka dapat dikatakan USG merupakan prediktor buruk untuk infeksi kongenital dengan gejala. ${ }^{6,8,22}$

\section{SIMPULAN}

Prevalensi infeksi sitomegalovirus (CMV) masih tinggi di negara berkembang, termasuk Indonesia. Infeksi CMV merupakan penyebab utama dari gangguan pendengaran pada masa anak-anak dan dapat menyebabkan gangguan perkembangan neurologis. Kewaspadaan terhadap infeksi CMV yang belum memadai dan biaya untuk mendeteksi secara laboratorik yang relatif masih tinggi menjadi perhatian bersama.

Untuk mendeteksi suatu kejadian infeksi CMV dapat dilakukan pemeriksaan tunggal maupun kombinasi. Pemeriksaan baku emas untuk infeksi CMV ialah kultur virus dari urin atau ludah. Pemeriksaan PCR menunjukkan sensitivitas dan spesifisitas yang tinggi. Pemeriksaan IgG dipakai untuk mendeteksi infeksi yang telah terjadi sebelumnya atau di masa lalu . Untuk membedakan infeksi primer dan non primer digunakan juga pemeriksaan IgG aviditas.

\section{DAFTAR PUSTAKA}

1. Malm G, Engman ML. Congenital cytomegalovirus infections. Seminars in Fetal \& Neonatal Medicine. 2007;12:154-9.

2. Plosa EJ, Esbenshade JC, Fuller MP, Weitkamp JH. Cytomegalovirus infection. Pediatr Rev. 2012;33(4):156-63.

3. Mussi-Pinhata MM, Yamamoto AY, Britto RMM, Isaac ML, Oliveira PFC, Boppana S, et al. Birth prevalence and natural history of congenital cytomegalovirus (CMV) infection in a highly seroimmune population. Clin Infect Dis. 2009;49(4):522-8.

4. Chen J, Hu L, Wu M, Zhong T, Zhou YH, Hu Y. Kinetics of IgG antibody to cytomegalovirus (CMV) after birth and seroprevalence of anti-cmv of a IgG in Chinese children. Virology. 2012;9:304.

5. Kadambari S, Williams EJ, Luck S, Griffiths PD, Sharland M. Evidence based management guidelines for the detection and treatment of congenital CMV. Early Hum Dev. 2011;87:723-8.

6. Johnson J, Anderson B, Pass RF. Prevention of maternal and congenital cytomegalovirus infection. Clin Obstet Gynecol. 2012;55(2):521-30.

7. Buonsenso D, Serranti D, Gargiullo L, Ceccarelli M, Ranno O, Valentini P. Congenital cytomegalovirus infection: current strategies and future perspectives. Eur Rev Med and Pharmacol Sci. 2012;16:919-35.

8. Hadinegoro SR, Chairulfatah A. In: Soedarmo SSP, Garna H, Hadinegoro SR, Satari HI, editors. Buku Ajar Infeksi \& Pediatri Tropis (Edisi ke-2). Jakarta: Badan Penerbit IDAI, 2012; p. 276-91.

9. Boppana SB, Fowler KB, Britt WJ, Stagno S, Pass RF. Symptomatic congenital cytomegalovirus infection in infants 
born to mothers with preexisting immunity to cytomegalovirus. Pediatrics. 1999;104:55-60.

10. Manicklal S, Emery VC, Lazzarotto T, Boppana S, Gupta RK. The "silent" global burden of congenital cytomegalovirus. Clin Microbiol Rev. 2013;26(1):86-102.

11. Cavlek TV, Sternak SL, Galinovic GM. Value of IgG avidity in cytomegalovirus infection diagnosis in pregnant women and newborn infants. Med Jad. 2008;38(1-2):23-8.

12. Ross SA, Novak Z, Pati S, Boppana SB. Diagnostic of cytomegalovirus infections. Infect Disord Drug Targets. 2011;11(5):466-74.

13. Jain M, Duggal S, Chugh TD. Cytomegalovirus infection in nonimmunosuppressed critically ill patients. J Infect Dev Ctries. 2011;5(8):571-9.

14. Munro SC, Hall B, Whybin LR, Leader L, Robertson P, Maine GT, et al. Diagnosis of and screening for cytomegalovirus infection in pregnant women. J Clin Microbiol. 2005;43(9):4713-8.

15. Vauloup-Fellous C, Ducroux A, Couloigner V, Marlin S, Picone O, Galimand $J$, et al. Evaluation of cytomegalovirus (CMV) DNA quantification in dried blood spots: retrospective study of CMV congenital infection. J Clin Microbiol. 2007;45(11):3804-6.

16. Ross SA, Novak Z, Fowler KB, Arora N, Britt WJ, Boppana SB. Cytomegalovirus blood viral load and hearing loss in young children with congenital infection. Pediatr Infect Dis J. 2009;28(7):588-92.
17. De Vries JJC, Wessels E, Korver AMH, van der Eijk AA, Rusman LG, Kroes ACM, et al. Rapid genotyping of cytomegalovirus in dried blood spots by multiplex real-time PCR assays targeting the envelope glycoprotein $\mathrm{gB}$ and $\mathrm{gH}$ genes. J Clin Microbiol. 2011;50(2):2327.

18. Boppana SB, Ross SA, Novak Z, Shimamura M, Tolan RW, Palmer AL, et al. Dried blood spot real-time polymerase chain reaction assays to screen newborns for congenital cytomegalovirus infection. JAMA. 2010;303(14):1375-82.

19. Prince HE, Leber AL. Validation of an inhouse assay for cytomegalovirus immunoglobulin G (CMV IgG) avidity and relationship of avidity to CMV IgM levels. Clin Diagn Lab Immunol. 2002;9(4):824-7.

20. Greanya ED, Partovi N, Yoshida EM, Shapiro RJ, Levy RD, Sherlock CH, et al. The role of the cytomegalovirus antigenemia assay in the detection and prevention of cytomegalovirus syndrome and disease in solid organ transplant recipients: a review of the British Columbia experience. Can J Infect Dis Med Microbiol. 2005;16(6):335-41.

21. Swanson EC, Schleiss MR. Congenital cytomegalovirus infection: new prospects for prevention and therapy. Pediatr Clin North Am. 2013;60(2):1-17.

22. Coll O, Benoist G, Ville Y, Weisman LE, Botet F, Anceschi MM, et al. Guidelines on CMV congenital infection. J Perinat Med. 2009;37:43345. 